\title{
Art, water and wellbeing
}

\author{
Angelika Spranger \\ Studio 601 Wimbledon Art Studios, London, UK \\ Correspondence to: Angelika Spranger. Studio 601 Wimbledon Art Studios, 10 Riverside Yard, Riverside Road, London SW17 0BB, UK. Email: \\ angelika@angelikaspranger.com.
}

Submitted Mar 24, 2020. Accepted for publication Jul 07, 2020.

doi: $10.21037 / \mathrm{cdt}-20-361$

View this article at: http://dx.doi.org/10.21037/cdt-20-361

Water in its various forms is omnipresent in this world. Nevertheless, the physical and mental benefits that water enhances our lives with are easily overlooked. Angelika Spranger feels connected to water and has a fascination with its role in sustaining the natural world (Figure 1).

She expresses this through her art and loves capturing water in unique ways to bring its beauty and importance to individuals and the wider public. By presenting her work without manipulation-all images are original and unedited-Angelika Spranger aligns her personal values of diligence and honesty with her professional life.

The importance of connecting with nature for wellbeing and better health, as well as recognising that we are water and that "There is only one water" which we all are connected through, is her inspiration for creation.

The concept of connecting artwork with scientific research excites the artist. Her photograph of a mother and a child taken through water was selected for the Tomorrow's Child Exhibition in the Houses of Parliament, London, UK (Figure 2).

Angelika collaborated with a leading child development expert to raise awareness of the importance of the very early years-from conception onwards-in a child's development.

Angelika's work includes limited edition photographs which are created as archival quality Giclee prints, C-type prints either framed or Perspex face mounted, or fused onto outdoor safe aluminium. This versatility allows her art to be displayed in challenging environments. As well as a passion for sharing water's innate beauty through photography, video, and immersive installations, Angelika Spranger is keen to start a discussion about water as a precious resource, a gift, and what it means to us.

\section{Still waters: let it flow. Allow the water to take you on a journey}

\section{Solo Show, gallery at St George's Hospital, London, UK (Figure 3)}

The artist on this exhibition: "With a degree in, and a passion for, Art for Public Space, I was delighted to be invited by the art director to curate a solo exhibition at the hospital's gallery. The brief I set myself was to design a space that could benefit all the people passing through the gallery, whether they be patients, staff, or visitors. Water plays such an important role in our lives, and humans are very receptive to its almost magical and grounding properties. For this show, the exhibition's primary focus was to place art in a public space in such a way that everyone could relate to, and benefit from it, in a healing space that invites mindfulness, a sense of calm, and meditation.

It was wonderful to receive feedback on the stills as well as on my first multi-media installation shared with this audience. I keep a visual notebook or diary, essentially a collection of short videos and photos of places that inspire me. Sharing my visual diary in the form of a projection onto a $3 \mathrm{D}$ installation helped recreate some tactile essence of water in this space and transpose nature into a clinical environment. This was specifically designed for this gallery space.

Hearing differing thoughts and perceptions about the art in St George's Hospital, during a panel discussion I organised, was hugely insightful. I love the idea of including art in everyday life and facilitating access for the broader public who might not otherwise engage with art. I am glad 


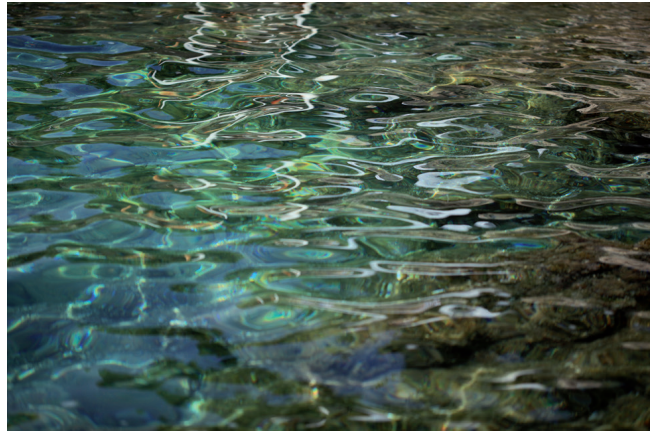

Figure 1 Adriatic Lyrics II. () Angelika Spranger.

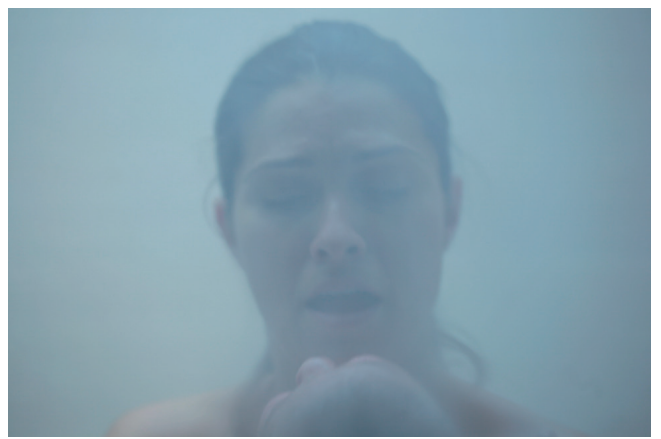

Figure 2 Origin I. (C) Angelika Spranger.

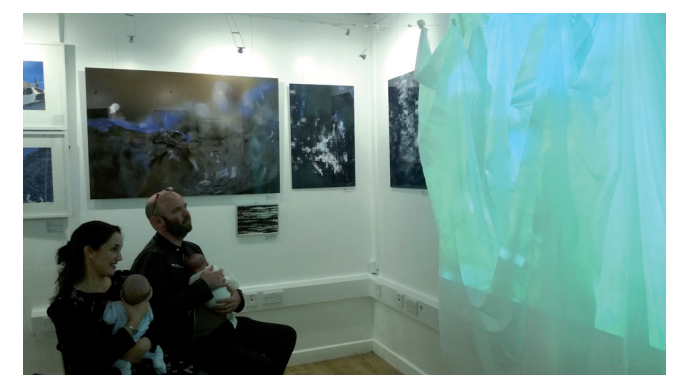

Figure 3 St George's Hospital. (C) Angelika Spranger.

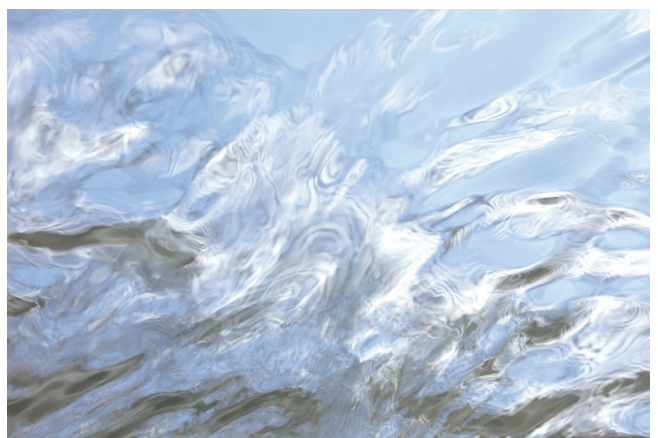

Figure 4 Water Frequency \# 423. (c) Angelika Spranger. that research has confirmed, that simply looking at art, nature, and water, reduces stress, anxiety, and calms the heart rate."

You can see a 2 min video of the exhibition here (Video 1).

\section{Still waters}

\section{Solo show, stable yard gallery, National Trust at Morden Hall Park, London, UK (Figure 4)}

The Water Frequency series exhibited at this solo exhibition was inspired by the unique way water responds to changing frequencies. Being largely made up of water ourselves, Angelika adopted an alternative way of capturing these photographs, allowing just sounds to guide and inspire her. This led to exciting results.

The artist's intention was for the visitor to visualise the connection between frequencies, water, and the spiritual self, through her art. Appreciating that we are water and that we each respond to frequencies in our own way was also a motivation behind this project. To illustrate this, the public were invited to join a guided water meditation with a qualified practitioner in the projection area, accompanied by sounds of water.

Angelika Spranger works in an almost meditative way and shares the highlights of her journeys with her audience, inviting them to find a moment for themselves to go on their own journeys.

\section{There is only one water}

\section{Public 3D installation and video projection at Wimbledon Art Fair, London, UK (Figure 5)}

This work is inspired by plastic pollution and plastic particles found in drinking water.

The 3D installation consists of a painting of water by Angelika with props attached. The centrepiece is a headless model symbolizing the crazy times we live in. There is also a plastic bottle containing fragmented plastics gathered at a 30-minute beach clean on Angelika's favourite area of the Cornish coast. It also consists of biodegradable coffee cup lids that unfortunately spoil plastic waste and mostly end up in landfill. Knowledge of how to recycle these properly, and the required facilities, are rare. In addition, plastic particles and related chemicals are found in drinking water. Angelika invites spectators to question their consumer habits and opt for more conscientious choices (Video 2).

The DNA triptych (Figure 6)—featured on this issue's 


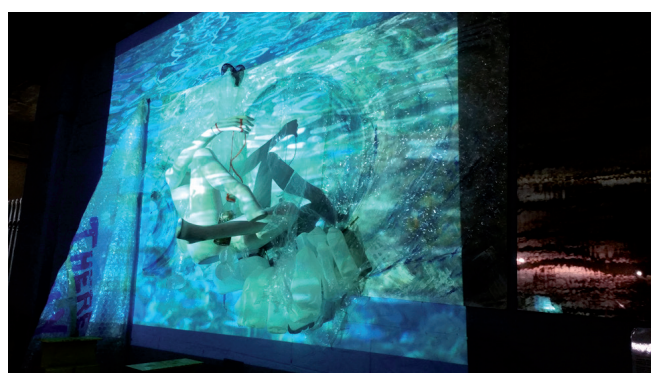

Figure 5 There Is Only One Water. (C) Angelika Spranger.

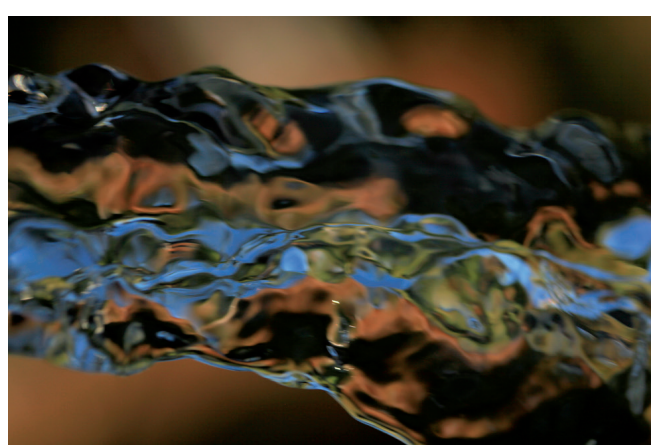

Figure 6 DNA III. (C) Angelika Spranger.

cover-was inspired by Angelika's interest in the structure of water.

Angelika completed a Foundation in Art and Design and studied Art for Public Space at Roehampton University, London, UK as a mature student. She gained her BA Art for Public space (First Class Hons) in 2005. Since 2010 she has been based in her SW London studio.

Angelika Spranger's work is exhibited at art fairs and galleries in and outside London. Her artwork is enjoyed in

Cite this article as: Spranger A. Art, water and wellbeing. Cardiovasc Diagn Ther 2021;11(2):696-698. doi: 10.21037/cdt20-361 public spaces and by private collectors.

It has been a pleasure to share parts of my journey here with you.

If you would like to know more, or to work with Angelika please get in contact: angelika@angelikaspranger. com; www.angelikaspranger.com; https://www.instagram. com/angelika_spranger_art_photo/.

\section{Acknowledgments}

Funding: None.

\section{Footnote}

Conflicts of Interest: The author has completed the ICMJE uniform disclosure form (available at http://dx.doi. org/10.21037/cdt-20-361). The author has no conflicts of interest to declare.

Ethical Statement: The author is accountable for all aspects of the work in ensuring that questions related to the accuracy or integrity of any part of the work are appropriately investigated and resolved.

Open Access Statement: This is an Open Access article distributed in accordance with the Creative Commons Attribution-NonCommercial-NoDerivs 4.0 International License (CC BY-NC-ND 4.0), which permits the noncommercial replication and distribution of the article with the strict proviso that no changes or edits are made and the original work is properly cited (including links to both the formal publication through the relevant DOI and the license). See: https://creativecommons.org/licenses/by-nc-nd/4.0/. 